\title{
Neuro epidemiology
}

Founded 1982 by B.S. Schoenberg, continued by M. Alter (1989-1996), P.B. Gorelick (1997-2000) and G.C. Román (2001-2007)

\section{Editor-in-Chief}

V.L. Feigin, Auckland

\section{Associate Editors}

G. Donnan, Melbourne

A. Hofman, Rotterdam

G. Logroscino, Boston, Mass.

\section{Assistant Editor}

J.A. Ford, Auckland

\section{Editorial Board}

A. Anand, Chandigarh

G.B.J. Anderson, Chicago, Ill.

A. Barber, Auckland

S. Barker-Collo, Auckland

E. Beghi, Milano

D.A. Bennett, Chicago, Ill.

D. Bennett, Oxford

F. Bermejo, Madrid

N.E. Bharucha, Mumbai

G. Boysen, Copenhagen

M.M.B. Breteler, Rotterdam

A. Culebras, Syracuse, N.Y.

R. D’Alessandro, Bologna

J.F. Dartigues, Bordeaux

J.L. Fisher, Columbus, Ohio

G.M. Franklin, Seattle, Wash.

A.J. Hannan, Melbourne

G. Hankey, Perth

W.A. Hauser, New York, N.Y.

C. Ketzoian, Montevideo
S.J. Kittner, Baltimore, Md.

A. Korczyn, Tel-Aviv

J.F. Kurtzke, Falls Church, Va.

S.-M. Lai, Kansas City, Kans.

M. Liu, Chengdu

E.D. Louis, New York, N.Y.

K. McPherson, Auckland

K. Nakashima, Yonago

L. Nelson, Stanford, Calif.

B. Norrving, Lund

P.-M. Preux, Limoges

A.H. Rajput, Saskatoon

K. Rockwood, Halifax

R.L. Sacco, Miami, Fla.

W.F. Stewart, Danville, Pa.

M. Thrift, Melbourne

T. Truelsen, Copenhagen

J. Tuomilehto, Helsinki

C. Tzourio, Paris

H. von Holst, Stockholm 
No. 1

Editorial

1 Capturing the Spectrum: Suggested Standards for Conducting Population-Based Traumatic Brain Injury Incidence Studies Barker-Collo, S.L.; Feigin, V.L. (Auckland)

Original Papers

4 Short- and Long-Term Prognosis among Veterans with Neurological Disorders and Subsequent Lower-Extremity Amputation

Prvu-Bettger, J.A. (Philadelphia, Pa.); Bates, B.E. (Albany, N.Y.); Bidelspach, D.E. (Lebanon, Pa.); Stineman, M.G. (Philadelphia, Pa.)

11 Incidence of Stroke Subtypes in the North East Melbourne Stroke Incidence Study (NEMESIS): Differences between Men and Women

Thrift, A.G. (Melbourne/Prahran); Dewey, H.M. (Melbourne); Sturm, J.W. (Melbourne/Sydney); Srikanth, V.K. (Clayton); Gilligan, A.K.

(Melbourne/Box Hill); Gall, S.L. (Melbourne/Hobart); Macdonell, R.A.L.

(Melbourne); McNeil, J.J. (Prahran); Donnan, G.A. (Melbourne)

Comment

19 Differences in Incidence of Stroke Subtypes between Men and Women

Hiraga, A. (Chiba)

Original Paper

21 Promoter Methylation and Polymorphisms of the MGMT Gene in Glioblastomas: A Population-Based Study Zawlik, I.; Vaccarella, S.; Kita, D. (Lyon); Mittelbronn, M. (Zurich); Franceschi, S.; Ohgaki, H. (Lyon)

Comment

30 The Impact of the DNA-Repair Gene MGMT in Malignant Gliomas

Hutterer, M. (Innsbruck)

Original Papers

32 Trends in Head Injury Incidence in New Zealand: A Hospital-Based Study from 1997/1998 to 2003/2004 Barker-Collo, S.L.; Wilde, N.J.; Feigin, V.L. (Auckland)

40 Relation of Hemoglobin to Level of Cognitive Function in Older Persons

Shah, R.C.; Wilson, R.S.; Tang, Y.; Dong, X. (Chicago, Ill.); Murray, A. (Minneapolis, Minn.); Bennett, D.A. (Chicago, Ill.)

47 The Female Stroke Survival Advantage: Relation to Age Olsen, T.S. (Hvidovre); Dehlendorff, C.; Andersen, K.K. (Lyngby)
53 Stroke Case Fatality Shows Seasonal Variation Regardless of Risk Factor Status in a Japanese Population: 15-Year Results from the Takashima Stroke Registry

Turin, T.C.; Kita, Y.; Rumana, N.; Murakami, Y. (Otsu); Ichikawa, M.; Sugihara, H.; Morita, Y. (Takashima); Tomioka, N. (Otsu); Okayama, A (Tokyo); Nakamura, Y. (Kyoto); Abbott, R.D. (Otsu/Charlottesville, Va.); Ueshima, H. (Otsu)

Methods in Neuroepidemiology

61 Linkage of Hospital and Death Records Increased Identification of Dementia Cases and Death Rate Estimates Zilkens, R.R.; Spilsbury, K. (Perth); Bruce, D.G. (Fremantle, W.A.); Semmens, J.B. (Perth)

Comment

70 Vital Records and Dementia

Kuller, L.H.; Ives, D.G. (Pittsburgh, Pa.)

Methods in Neuroepidemiology

72 Smoking Status over Two Years in Patients with Multiple Sclerosis

Marrie, R.A. (Winnipeg, Man.); Cutter, G. (Birmingham, Ala.); Tyry, T.; Campagnolo, D.; Vollmer, T. (Phoenix, Ariz.)

Comment

80 Different Risk Factors in Vascular Dementia and Ischaemic Stroke

Potluri, R.; Natalwala, A.; Uppal, H.; Heun, R. (Birmingham)

No. 2

Original Papers

81 Geographical Clustering of Amyotrophic Lateral Sclerosis in South-East England: A Population Study

Scott, K.M.; Abhinav, K.; Stanton, B.R.; Johnston, C.; Turner, M.R.; Ampong, M.-A. (London); Sakel, M. (Dover); Orrell, R.W.; Howard, R.; Shaw, C.E.; Leigh, P.N.; Al-Chalabi, A. (London)

89 The Prevalence of Hereditary Spastic Paraplegia and the Occurrence of SPG4 Mutations in Estonia Braschinsky, M.; Lüüs, S.-M. (Tartu); Gross-Paju, K. (Tallinn); Haldre, S. (Tartu)

94 Six-Year Survival and Causes of Death among Stroke Patients in Korea

Kim, H.C. (Seoul/Chicago, Ill.); Choi, D.P.; Ahn, S.V.; Nam, C.M.; Suh, I (Seoul)

\section{KARGER}

Fax +41 613061234 E-Mail karger@karger.ch www.karger.com

\section{2009 S. Karger AG, Basel}

Access to full text and tables of contents, including tentative ones for forthcoming issues: www.karger.com/ned_issues 
101 Prevalence of Dementia in the Rural Island Town of Ama-cho, Japan

Wada-Isoe, K.; Uemura, Y.; Suto, Y.; Doi, K.; Imamura, K.; Hayashi, A.; Kitayama, M.; Watanabe, Y. (Yonago); Adachi, Y. (Yonago/Matsue); Nakashima, K. (Yonago)

107 High Incidence of Respiratory Infections in 'Nil by Mouth' Tube-Fed Acute Ischemic Stroke Patients

Langdon, P.C.; Lee, A.H.; Binns, C.W. (Perth, W.A.)

114 Active and Passive Smoking and Risk of Narcolepsy in People with HLA DQB1*0602: A Population-Based Case-Control Study Ton, T.G.N.; Longstreth, W.T., Jr.; Koepsell, T. (Seattle, Wash.)

122 A Population-Based Study of the Association between Trypanosoma cruzi Infection and Cognitive Impairment in Old Age (The Bambuí Study)

Lima-Costa, M.F. (Belo Horizonte); Castro-Costa, E.

(Belo Horizonte/London); Uchôa, E.; Firmo, J.; Ribeiro, A.L.P.

(Belo Horizonte); Ferri, C.P.; Prince, M. (London)

129 Epidemiological Survey of Epilepsy in the Special School Population in the City of Buenos Aires. A Comparison with Mainstream Schools

Somoza, M.J.; Forlenza, R.H.; Brussino, M.; Centurión, E. (Buenos Aires)

136 Clinicoepidemiological Profiles and Outcomes during First Hospital Admission of Head Injury Patients in Ikeja, Nigeria A Prospective Cohort Study

Adeleye, A.O. (Ibadan); Olowookere, K.G. (Ikeja); Olayemi, O.O. (Ibadan)

142 Acute Treatment Costs of Stroke in Brazil

Christensen, M.C. (Bagsvaerd); Valiente, R.; Sampaio Silva, G. (São Paulo); Lee, W.C.; Dutcher, S. (Bethesda, Md.); Guimarães Rocha, M.S.; Massaro, A. (São Paulo)

Review

150 The Epidemiology of Guillain-Barré Syndrome Worldwide A Systematic Literature Review

McGrogan, A. (Bath); Madle, G.C.; Seaman, H.E. (Guildford); de Vries, C.S. (Bath)

Letter to the Editor

164 A Medical Enigma: Persons with Down Syndrome Do Not Develop Medulloblastoma

Satgé, D. (Tulle); Rickert, C.H. (Melbourne)

No. 3

Original Papers

165 Patterns of Influenza Vaccination among Stroke Survivors Sanossian, N.; Gatto, N.M.; Ovbiagele, B. (Los Angeles, Calif.)

171 Prevalence of Possible Idiopathic Normal-Pressure Hydrocephalus in Japan: The Osaki-Tajiri Project Tanaka, N. (Sendai/Kawasaki); Yamaguchi, S. (Sendai/Osaki); Ishikawa, H. (Sendai); Ishii, H. (Sendai/Kawasaki); Meguro, K. (Sendai/Osaki)

176 Prevalence of Spinocerebellar Degenerations in the Hokuriku District in Japan

Shibata-Hamaguchi, A.; Ishida, C.; Iwasa, K.; Yamada, M. (Kanazawa)

Comment

184 Spinocerebellar Degenerations in Japan. New Insights from an Epidemiological Study

Teive, H.A.G. (Curitiba)
Original Papers

186 Community-Based Study of Stroke Incidence in the Valley of Aosta, Italy. CARe-Cerebrovascular Aosta Registry: Years 2004-2005

Corso, G.; Bottacchi, E.; Giardini, G.; De la Pierre, F.; Meloni, T.; Pesenti Campagnoni, M.; Ponzetti, C.; Veronese Morosini, M. (Aosta)

196 Smoking Cessation at 5 Years after Stroke in the North East Melbourne Stroke Incidence Study

Gall, S.L. (Hobart, Tas./Heidelberg Heights, Vic./Parkville, Vic.) Dewey, H.M. (Heidelberg Heights, Vic./Heidelberg, Vic./Parkville, Vic.); Thrift, A.G. (Heidelberg Heights, Vic./Melbourne, Vic.)

201 Classic Risk Factors for Atherosclerosis Are Not Major Determinants for Location of Extracranial or Intracranial Cerebral Atherosclerosis

Kim, Y.D.; Choi, H.Y.; Jung, Y.H.; Nam, C.M.; Yang, J.H.; Cho, H.J.; Nam, H.S.; Lee, K.Y.; Heo, J.H. (Seoul)

208 Prevalence of Essential Tremor in a Multiethnic, CommunityBased Study in Northern Manhattan, New York, N.Y. Louis, E.D.; Thawani, S.P.; Andrews, H.F. (New York, N.Y.)

Comment

215 How Common Is Essential Tremor? Benito-León, J. (Madrid)

Original Paper

217 Incidence of Traumatic Peripheral Nerve Injuries and Amputations in Sweden between 1998 and 2006 Asplund, M.; Nilsson, M. (Huddinge); Jacobsson, A. (Stockholm); von Holst, H. (Huddinge/Stockholm)

Methods in Neuroepidemiology

229 Adjustment for Selection Bias in Observational Studies with Application to the Analysis of Autopsy Data

Haneuse, S. (Seattle, Wash.); Schildcrout, J. (Nashville, Tenn.); Crane, P.; Sonnen, J.; Breitner, J.; Larson, E. (Seattle, Wash.)

Comment

240 Selection Bias. Importance of Identification and Adjustment Carter, K.N.; Blakely, T. (Wellington)

Selected Abstracts

2421 st Egyptian International Neuroepidemiology Conference Luxor, Egypt, February 10-13, 2009

(only available online)

No. 4

Original Papers

251 Fruit and Vegetable Intake and Risk of Amyotrophic Lateral Sclerosis in Japan

Okamoto, K. (Nagoya); Kihira, T. (Osaka); Kobashi, G. (Chiba); Washio, M. (Fukuoka); Sasaki, S. (Wako); Yokoyama, T. (Tokyo); Miyake, Y. (Fukuoka); Sakamoto, N. (Nishinomiya); Inaba, Y. (Tokyo); Nagai, M. (Saitama)

257 Association of Infectious Mononucleosis with Multiple Sclerosis. A Population-Based Study

Ramagopalan, S.V.; Valdar, W.; Dyment, D.A.; DeLuca, G.C. (Oxford); Yee, I. M. (Vancouver, B.C.); Giovannoni, G. (London); Ebers, G.C. (Oxford); Sadovnick, A.D. (Vancouver, B.C.) for the Canadian Collaborative Study Group 
263 Changes in Prevalence and Incidence of Parkinson's Disease in Japan during a Quarter of a Century

Yamawaki, M.; Kusumi, M.; Kowa, H.; Nakashima, K. (Yonago)

270 Very Low Prenatal Exposure to Lead and Mental Development of Children in Infancy and Early Childhood. Krakow Prospective Cohort Study

Jedrychowski, W. (Krakow); Perera, F.P.; Jankowski, J. (New York, N.Y.); Mrozek-Budzyn, D.; Mroz, E.; Flak, E. (Krakow); Edwards, S. (New York, N.Y.); Skarupa, A.; Lisowska-Miszczyk, I. (Krakow)

287 Prevalence and Incidence of Multiple Sclerosis in Panama (2000-2005)

Gracia, F.; Castillo, L.C.; Benzadón, A.; Larreategui, M.; Villareal, F.; Triana, E.; Arango, A.C.; Lee, D.; Pascale, J.M.; Gomez, E.; Armien, B. (Panamá)

Comment

294 Multiple Sclerosis in Latin America. Reality and Challenge Rivera, V.M. (Houston, Tex.)

Original Papers

296 Dietary Total Fat Intake and Ischemic Stroke Risk: The Northern Manhattan Study

Boden-Albala, B.; Elkind, M.S.V.; White, H.; Szumski, A.; Paik, M.C. (New York, N.Y.); Sacco, R.L. (Miami, Fla.)

302 Recent Racial/Ethnic Disparities in Stroke Hospitalizations and Outcomes for Young Adults in Florida, 2001-2006

Pathak, E.B.; Sloan, M.A. (Tampa, Fla.)
Comment

312 Racial/Ethnic Differences in Stroke in Young Adults Allen, N. (New Haven, Conn.)

Methods in Neuroepidemiology

279 Thrombolysis in Acute Childhood Stroke: Design and Challenges of the Thrombolysis in Pediatric Stroke Clinical Trial

Amlie-Lefond, C. (Milwaukee, Wisc.); Chan, A.K.C. (Hamilton, Ont.); Kirton, A. (Calgary, Alta.); deVeber, G. (Toronto, Ont.); Hovinga, C.A. (Memphis, Tenn.); Ichord, R. (Philadelphia, Pa.); Stephens, D. (Toronto, Ont.); Zaidat, O.O. (Milwaukee, Wisc.) The Thrombolysis in Pediatric Stroke (TIPS) Investigators

313 A Screening Instrument to Measure the Prevalence of Neurological Disability in Resource-Poor Settings Bower, J.H. (Rochester, Minn.); Howlett, W.; Maro, V.P.; Wangai, H.; Sirima, N.; Reyburn, H. (Moshi)

321 Author Index Vol. 32, 2009

322 Subject Index Vol. 32, 2009

\section{S. Karger}

Medical and Scientific Publishers

Basel $\cdot$ Freiburg $\cdot$ Paris $\cdot$ London .

New York $•$ Bangalore $\cdot$ Bangkok .

Shanghai $\cdot$ Singapore $\cdot$ Tokyo $\cdot$ Sydney
Disclaimer

The statements, opinions and data contained in this publication are solely those of the individual authors and contributors and not of the publisher and the editor(s). The appearance of advertisements in the journal is not a warranty, endorsement or approval of the products or services advertised or of thei effectiveness, quality or safety. The publisher and the editor(s) disclaim responsibility for any injury to persons or property resulting from any ideas, methods, instructions or products referred to in the content or advertisements.

Drug Dosage

The authors and the publisher have exerted every effort to ensure that drug selection and dosage set forth in this text are in accord with current recommendations and practice at the time of publication. However, in view of ongoing research, changes in government regulations, and the constant flow of information relating to drug therapy and drug reactions, the reader is urged to check the package insert for each drug for any change in indications and dosage and for added warnings and precautions. This is particularly important when the recommended agent is a new and/or infrequently employed drug.
All rights reserved.

No part of this publication may be translated into other languages, reproduced or utilized in any form or by any means, electronic or mechanical, including photocopying, recording, microcopying, or by any information storage and retrieval system, without permission in writing from the publisher or, in the case of photocopying, direct payment of a specified fee to the Copyright Clearance Center (see 'General Information').

(c) Copyright 2009 by S. Karger AG

P.O. Box, CH-4009 Basel (Switzerland) Printed in Switzerland

on acid-free and non-aging paper (ISO 9706) by

Reinhardt Druck, Basel 